\title{
Balloon Cell Malignant Melanoma in a Young Female: A Case Report and Review of the Literature
}

\author{
Yui Hattori ${ }^{\mathrm{a}}$ Kazuhiro Sentani $^{\mathrm{a}}$ Takuya Hattori $^{\mathrm{a}}$ Yoshimi Matsuo $^{\mathrm{b}, \mathrm{c}}$ \\ Mikio Kawai ${ }^{b}$ Hajime Shindo $^{d}$ Maiko Tanaka ${ }^{b}$ Michihiro Hide ${ }^{b}$ \\ Wataru Yasui ${ }^{\mathrm{a}}$ \\ Departments of ${ }^{a}$ Molecular Pathology and ${ }^{b}$ Dermatology, Hiroshima University Institute of \\ Biomedical and Health Sciences, 'Department of Dermatology, Hiroshima Kyoritsu \\ Hospital, and ${ }^{\mathrm{d}}$ Shindo Dermatology and Allergy Clinic, Hiroshima, Japan
}

\section{Key Words}

Balloon cell malignant melanoma · Foamy cell · Histopathology · Immunohistochemistry · Lymph node metastasis

\begin{abstract}
Balloon cell malignant melanoma ( $\mathrm{BCMM})$ is a very rare malignant melanoma subtype. The clinical appearance of BCMM varies; it may be nodular, ulcerated, polypoid, papillomatous and often non-pigmented. The tumor cells histologically appear large, polygonal or round and contain abundant granular or vacuolated cytoplasm. We herein report the case of a 32year-old female who presented with a focal eccentric pigmented mass in the left lumbar region of $15 \mathrm{~mm}$ in diameter that had been present for several years. She underwent tumor excision. The histopathological analysis showed epithelioid melanocytes with clear cytoplasm. An immunohistochemical analysis revealed that the cells were positive for HMB-45 and S-100 protein and negative for cytokeratin. The balloon cell component stained negative for Fontana-Masson. A month later, the patient underwent excision of the bilateral inguinal lymph nodes and metastatic BCMM was revealed. The lymph node metastases showed the complete replacement of lymph nodes by balloon cells. A diagnosis of BCMM (Breslow depth 10 $\mathrm{mm}$, Clark level V) without ulcer was rendered. Staining with $\mathrm{Ki}-67$ was positive in almost $44 \%$ of the balloon cells.

2016 The Author(s)

Published by S. Karger AG, Basel
\end{abstract}

\section{KARGER}

Wataru Yasui, MD, PhD

Department of Molecular Pathology

Hiroshima University Institute of Biomedical and Health Sciences

1-2-3 Kasumi, Minami-ku, Hiroshima 734-8551 (Japan)

E-Mail wyasui@hiroshima-u.ac.jp 
Hattori et al.: Balloon Cell Malignant Melanoma in a Young Female: A Case Report and Review of the Literature

\section{Introduction}

Malignant melanoma is a malignant tumor of the melanocytes or the cells that develop from melanocytes. Histologically, malignant melanomas are asymmetrical and poorly circumscribed lesions with architectural disturbance and usually marked cytological atypia. They consist of large pleomorphic cells, small cells and spindle cells. The major histologic subtypes of melanoma are superficial spreading melanoma, nodular melanoma, lentigo maligna melanoma and acral lentiginous melanoma, which show a variety of cytomorphological features, architectural patterns and stromal changes that may be observed in malignant melanomas. Moreover, there are numerous uncommon histological variants, including clear, signet ring, pseudolipoblastic, rhabdoid, plasmacytoid and balloon cell melanomas.

Among them, balloon cell malignant melanoma (BCMM) is the rarest variant composed of large, polygonal, foamy cells with abundant cytoplasm [1]. These features can also be seen in balloon cell nevus (BCN), but the presence of nuclear pleomorphism, atypia, mitoses and a lack of maturation of melanocytes with descent into the dermis help to differentiate BCMM [1]. A balloon cell change may occasionally be observed in conventional melanomas, but it mostly remains in focal areas. Kao et al. [1] defined BCMM as a melanoma composed of more than $50 \%$ of foamy cells. Malignant melanoma accounts for only 3-5\% of primary cutaneous malignancies and it mostly develops in people over 50 years. This report presents a young patient of primary BCMM with near-complete effacement by foamy cells.

\section{Case Presentation}

A 32-year-old female presented to our hospital with a tumor on the left lumbar region. She had no personal or family history of skin cancer. The lesion of concern was an erythematous and focal eccentric pigmented nodule of $15 \mathrm{~mm}$ in diameter (fig. 1a). The clinical appearance of the lesion raised a suspicion of malignancy, and surgical resection was performed.

The surgically resected specimen showed a nodule with focally pigmented areas, and the cut surface of the nodule was asymmetrical and not ulcerated. Histological examinations showed a skin fragment with nearly complete effacement by foamy cells and asymmetry (fig. 1b). The foamy cells in the superficial dermis extended to the fatty tissue to a depth of 10 $\mathrm{mm}$. Nuclear atypia and mitosis were scarcely displayed (fig. 1c). The intraepidermal component was composed of both nested and single atypical melanocytes with areas of intraepidermal pagetoid spread (fig. 1d). Fontana-Masson staining of the balloon cell component was negative (fig. 2a). An immunohistochemical analysis revealed that the balloon cells were positive with HMB-45 (fig. 2b) and S-100 protein (fig. 2c) and negative with cytokeratin. Staining with Ki-67 was positive in almost $44 \%$ of the foamy cells (fig. $2 \mathrm{~d}$ ). The pathological diagnosis was of BCMM (Breslow depth $10 \mathrm{~mm}$, Clark level V) without ulcer.

A month after the excision, the patient presented with enlarged bilateral inguinal lymph nodes. The excised bilateral inguinal lymph nodes showed diffuse replacement of the lymph nodes by foamy cells (fig. 1e, f). These cells resembled those of the primary lesion. The diagnosis of a metastatic BCMM in bilateral inguinal lymph nodes was made. The final diagnosis was of Stage IIIB (T4a, N2b, M0). She received additional local excision, but not chemotherapies on her request. 
Hattori et al.: Balloon Cell Malignant Melanoma in a Young Female: A Case Report and Review of the Literature

\section{Discussion}

BCMM is an uncommon histopathological subtype of malignant melanoma that was first described by Gardner and Vazquez in 1970 [2]. BCN was first described over 100 years ago. Since then, balloon cell changes of melanocytes have been noted in numerous neoplasms, including melanoma. Histologically differential diagnosis of BCMM includes BCN, clear cell sarcoma, clear cell metastatic renal cell carcinoma, basal cell carcinoma, squamous cell carcinoma and dermatofibroma.

The lesion reported here presented as an erythematous nodule with focal peripheral pigmentation. The clinical appearance could also be interpreted as that of Spitz nevus, basal cell carcinoma, eccrine poroma or eccrine porocarcinoma. A microscopic examination showed a dominant nodular component comprised exclusively of markedly distended epithelioid melanocytes showing abundant vacuolated cytoplasm.

A feature of BCMM is the aggregation of balloon cells [3]. BCMM differs from BCN in its nuclear pleomorphism, atypia and the lack of melanocyte maturation with a decent proliferation into the dermis [1]. While Fontana-Masson staining of melanoma cells is generally positive, balloon cells in BCMM are generally negative in this stain [4-7]. Moreover, mitosis is absent or rare in BCMM [8]. The balloon cell component of our current case was also stained negative with Fontana-Masson. However, it showed an increased Ki-67 index, suggesting a high mitotic activity.

The detailed mechanism of the balloon cell change is a matter of discussion. The occurrence of the foamy cells has been suggested to be related to an enlarged defective melanosome formation [9]. They are likely developed by the transformation of epithelioid cells, because balloon cells are mainly observed at metastatic or recurring lesions.

Previous case reports suggested that patients with BCMM may have longer survivals than those without balloon cell changes [10]. However, the actual mortality rate of BCMM tends to be high because BCMM are thick at the time of presentation. In fact, there was no apparent difference in a more recently reported survival rate between BCMM and other variants of melanoma [9]. Malignant melanoma may affect people of all ages but is mostly observed in people over the age of 50 years. The case reported here is a young case of primary BCMM with near-complete effacement by foamy cells.

\section{Statement of Ethics}

The authors have no ethical conflicts to disclose.

\section{Disclosure Statement}

The authors have no conflicts of interest to declare.

\section{References}

1 Kao GF, Helwig EB, Graham JH: Balloon cell malignant melanoma of the skin. A clinicopathologic study of 34 cases with histochemical, immunohistochemical, and ultrastructural observations. Cancer 1992;69:29422952.

-2 Gardner WA Jr, Vazquez MD: Balloon cell melanoma. Arch Pathol 1970;89:470-472. 


\section{Case Reports in Oncology}

\begin{tabular}{l|l}
\hline Case Rep Oncol 2016;9:262-266 \\
\hline DOI: 10.1159/000446065 & $\begin{array}{l}\text { ○ 2016 The Author(s). Published by S. Karger AG, Basel } \\
\text { www.karger.com/cro }\end{array}$ \\
\hline
\end{tabular}

Hattori et al.: Balloon Cell Malignant Melanoma in a Young Female: A Case Report and Review of the Literature

-3 Lee L, Zhou F, Simms A, Wieczorek R, Fang Y, Subietas-Mayol A, Wang B, Heller P, Huang H, Pei Z, Osman I, Meehan S, Lee P: Metastatic balloon cell malignant melanoma: a case report and literature review. Int J Clin Exp Pathol 2011;4:315-321.

-4 Aloi FG, Coverlizza S, Pippione M: Balloon cell melanoma: a report of two cases. J Cutan Pathol 1988;15:230233.

5 Ranchod M: Metastatic melanoma with balloon cell changes. Cancer 1972;30:1006-1013.

6 Mowat A, Reid R, Mackie R: Balloon cell metastatic melanoma: an important differential in the diagnosis of clear cell tumours. Histopathology 1994;24:469-472.

-7 Peters MS, Su WP: Balloon cell malignant melanoma. J Am Acad Dermatol 1985;13:351-354.

-8 Northcutt AD: Epidermotropic xanthoma mimicking balloon cell melanoma. Am J Dermatopathol 2000;22:176-178.

-9 Magro CM, Crowson AN, Mihm MC: Unusual variants of malignant melanoma. Mod Pathol 2006;19(suppl 2):S41-S70.

10 Friedman M, Rao U, Fox S: The cytology of metastatic balloon cell melanoma. Acta Cytol 1982;26:39-43.
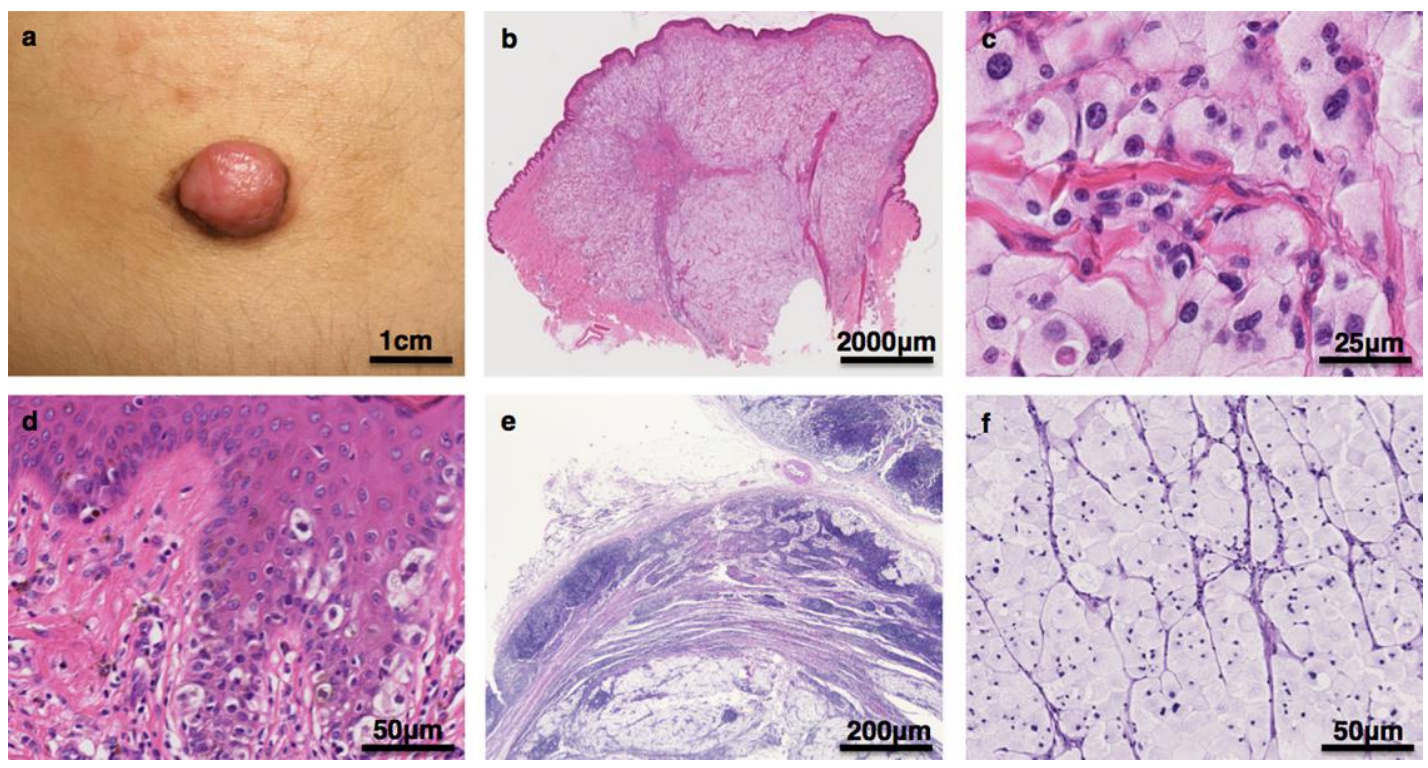

Fig. 1. a Close-up image of an erythematous nodule on the left lumbar region of a 32-year-old woman. b A low-power dermatopathologic view of the lesion, which was comprised exclusively of markedly distended epithelioid melanocytes showing abundant clear cytoplasm. c A high-power view in which the balloon cell component, nuclear pleomorphism and atypia are identified. $\mathbf{d}$ The intraepidermal component composed of both nested and single atypical melanocytes with some areas of intraepidermal pagetoid spread. e, $\mathbf{f}$ The lymph nodes show near-complete replacement with balloon melanoma cells. 


\section{Case Reports in Oncology}

\begin{tabular}{l|l}
\hline Case Rep Oncol 2016;9:262-266 \\
\hline DOI: $10.1159 / 000446065$ & $\begin{array}{l}\text { (c) 2016 The Author(s). Published by S. Karger AG, Basel } \\
\text { www.karger.com/cro }\end{array}$ \\
\hline
\end{tabular}

Hattori et al.: Balloon Cell Malignant Melanoma in a Young Female: A Case Report and Review of the Literature
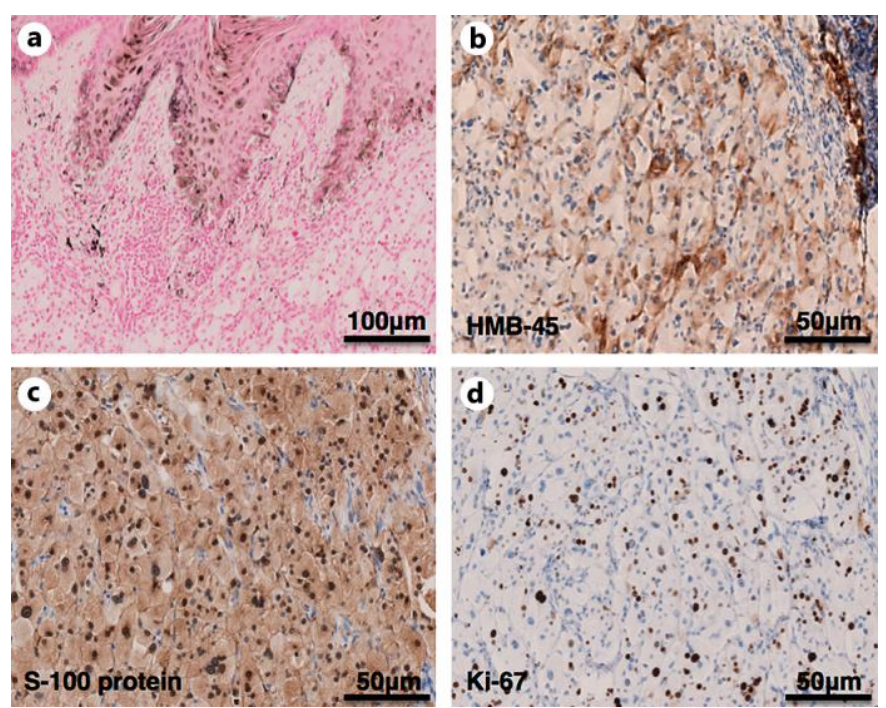

Fig. 2. a An immunohistochemical staining of the balloon cell component with Fontana-Masson stain was negative. Immunohistochemical staining of the tumor mass was positive with HMB-45 (b) and S-100 (c). d There was an increased Ki-67 index in the balloon cell component. 